\title{
Обзор Второй международной научно-практической конференции «Абовские чтения»
}

18 ноября 2020 г. в Институте государства и права РАН состоялась Вторая международная научно-практическая конференция «Абовские чтения» на тему: «Возникновение гражданских и семейных прав и их защита: традиционные и новые подходы». Организатором конференции выступил сектор гражданского права, гражданского и арбитражного процесса ИГП РАН. В работе конференции приняли участие судьи Верховного Суда РФ и Суда Евразийского экономического союза (ЕАЭС), ведущие отечественные и зарубежные ученые - представители академических институтов и образовательных организаций, представители органов государственной власти и практикующие юристы.

Конференция была посвящена памяти выдающегося ученого и правоведа, Заслуженного деятеля науки Российской Федерации, доктора юридических наук, профрессора Тамары Евгеньевны Абовой, и традиционно проводилась в день ее рождения. Формат работы конференции - смешанный: в Институте в очном формате работали президиум пленарного заседания и модераторы секций, связь с остальными участниками осуществлялась в режиме веб-конференции. В конференции приняли участие коллеги из 42 вузов и научных организаций из 18 городов России, Казахстана и Республики Беларусь. Участниками конференции выступили 81 кандидат юридических наук, 26 докторов юридических наук, представители Верховного Суда РФ и Суда ЕАЭС, 22 практикующих юриста, аспиранты и студенты из ИГП РАН, МГУ имени М. В. Ломоносова, ИЗиСП, СПбГУ, МГЮА, МГИМО, ВАВТ, РГУП, ВГУЮ, УрГЮУ, СГЮА, Сибирского федерального университета, Казанского федерального университета, Самарского национального исследовательского университета, МВШСЭН, Воронежского государственного университета, Финансового университета, РАНХиГС, Тольяттинского государственного университета, Университета ФСИН России, РГУ нефти и газа имени Губкина, Московского гуманитарного университета, ТвГУ, Сибирского института управления - фрилиала РАНХиГС, Белорусского государственного университета, СКФУ, Филиала РГСУ в г. Клин Московской обл.

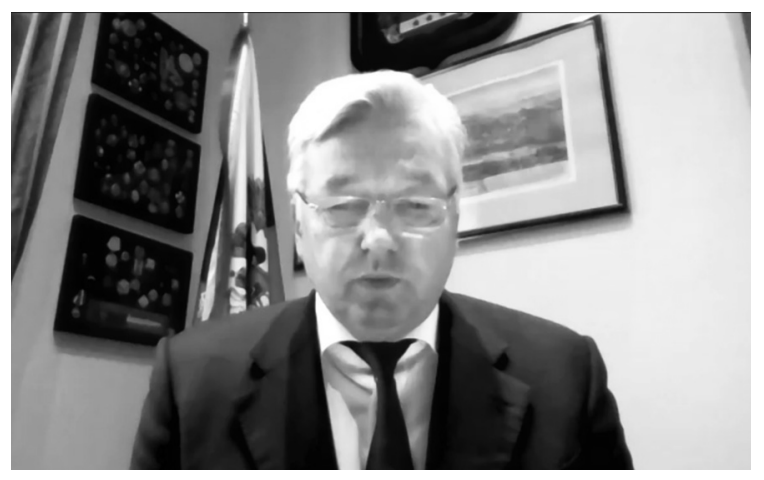

Модераторами пленарного заседания выступили и. о. зам. директора ИГП РАН по научной работе, д-р юрид. наук Н. В. Летова и и. о. зав. сектором гражданского права, гражданского и арбитражного процесса, д-р юрид. наук, профр. С. С. Занковский.

Открыл работу конференции, обратившись с приветственным словом к участникам 
мероприятия, директор ИГП РАН чл.-корр. РАН, д-р юрид. наук, проф., Заслуженный юрист Российской Федерации А. Н. Савенков. Осветив творческое наследие Т. Е. Абовой, он отметил, что идеи Тамары Евгеньевны не утрачивают своей актуальности, а напротив, находят практическую реализацию в настоящее время. Одним

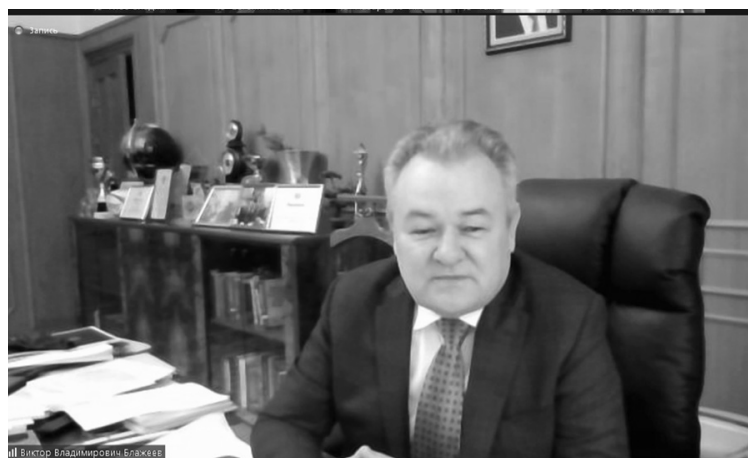
из примеров таковой является создание в рамках ИГП РАН научных центров с целью комплексного развития связанных отраслей права путем объединения научных усилий в различных научных направлениях.

Отдал дань памяти Т. Е. Абовой в своем докладе ректор Московского государственного юридического университета им. О. Е. Кутафина (МГЮА) канд. юрид. наук, проф., Заслуженный юрист Российской Федерации В. В. Блажеев, отметив тесную связь между процессуальными школами МГЮА и ИГП РАН. Объяснение этой связи в том, что Тамара Евгеньевна была первым аспирантом известного ученого-процессуалиста Марка Аркадьевича Гурвича, много лет работавшего в ВЮЗИ (ныне МГЮА). В связи с внесенными в ст. 118 Кон-

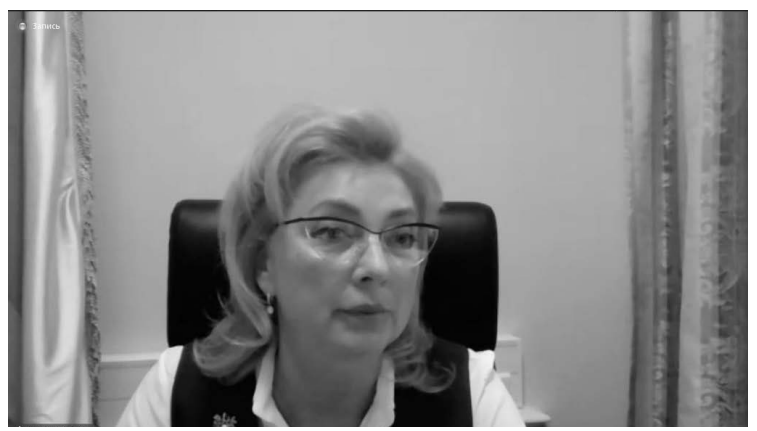
ституции изменениями Виктор Владимирович напомнил, что Тамара Евгеньевна последовательно отстаивала идею самостоятельности арбитражного судопроизводства.

В своем выступлении заверила участников конференции в поддержке традиции «Абовских чтений» Верховным Судом РФ Т. Н. Назаренко, судья Верховного Суда РФ, канд. юрид. наук, доц. В докладе, посвященном роли Верховного Суда Российской Федерации в формировании судебной практики по семейным делам, она подняла проблему соотношения гражданского и семейного права, подчеркнув при этом необходимость учета семейного права в качестве самостоятельной отрасли права.

Судья Суда ЕАЭС , зав. кафедрой международного права РГУП, д-р юрид. наук, профрессор Т. Н. Нешатаева подключилась к конференции из Минска. В своем докладе о влиянии судоустройства на процесс защиты гражданских прав Татьяна

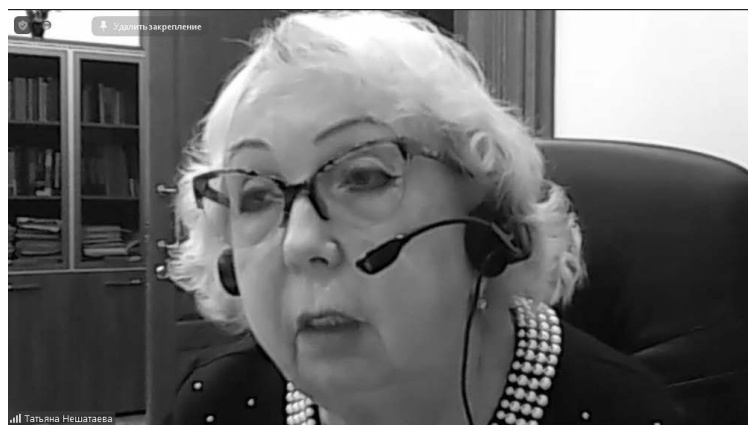




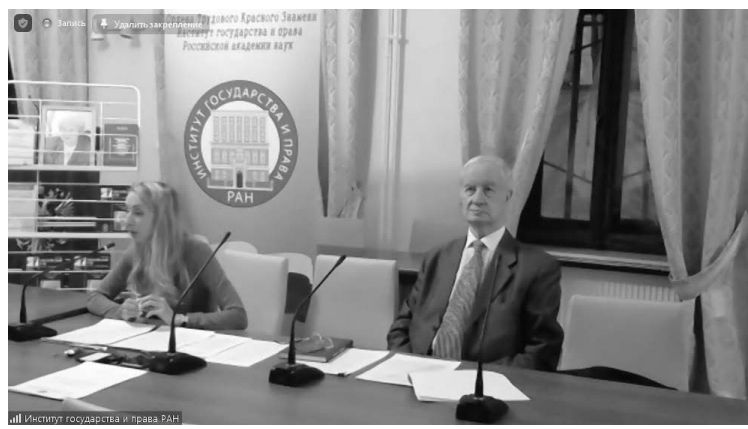

Николаевна рассказала о проблемах, связанных с созданием единообразной практики суда ЕАЭС, и предложила меры судоустройственного характера, которые позволили бы решить проблему единообразного правоприменения.

\section{Алексей Александрович}

Костин, Председатель Международного коммерческого арбитражного суда и Морской арбитражной комиссии при Торгово-промышленной палате РФ, зав. кафедрой международного частного и гражданского права МГИМО, канд. юрид. наук, проф., выступил с докладом «О Тамаре Евгеньевна Абовой - Арбитре и Учителе».

Алексей Александрович назвал Тамару Евгеньевну одним из идейных руководителей кафедры международного частного права МГИМО, принимавшим активное участие в ее становлении и деятельности. Он отметил тонкое понимание Тамарой Евгеньевной различий между процедурой арбитража и разбирательством в государственных арбитражных судах, ее демократичный характер, которые позволили ей стать авторитетным арбитром и получить огромный опыт участия в арбитражных разбирательствах. А. А. Костин напомнил, что свою деятельность в качестве арбитра Тамара Евгеньевна начинала в Морской арбитражной комиссии при ТПП СССР.

В докладе была подвергнута критике продолжающаяся практика арбитражных судов без законных на то оснований и объяснения мотивов отменять решения международного коммерческого арбитража в связи с нарушением публичного порядка, отождествляя это основание с иными основаниями к отмене решений международного коммерческого арбитража или нарушением принципа законности, основополагающих принципов российского права. Опасность такой судебной практики в том, что она, игнорируя значение «публичного порядка» как основания ultima ratio, последнего довода, когда никакие другие основания неприменимы, приводит к неоправданному росту числа отменяемых третейских и арбитражных решений, демонстрируя «непроарбитражный подход» российских государственных судов. А. А. Костин высказал надежду, что с учетом Постановления Пленума Верховного Суда от 10.12.2019 № 53 «О выполнении судами Российской Федерации функций содействия и контроля в отношении третейского разбирательства, международного коммерческого арбитража» подходы российских государственных судов будут меняться.

На пленарном заседании состоялась презентация сборника материалов Первой международной научно-практической конференции «Абовские

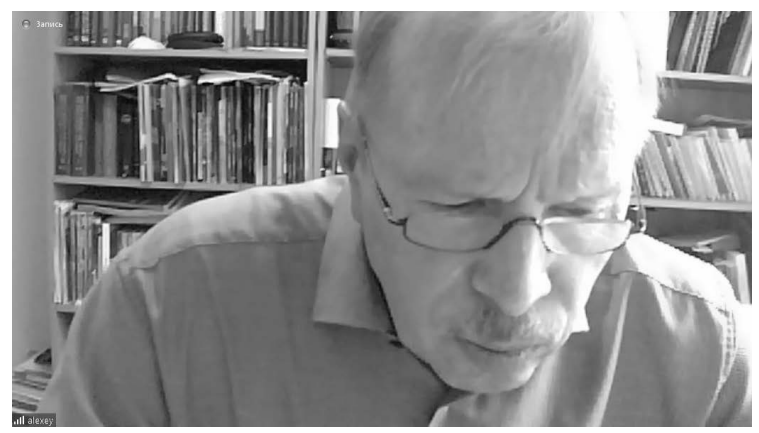


чтения»: «Фундаментальные проблемы и перспективы гражданского и предпринимательского права, гражданского и арбитражного процесса в современных экономических условиях». Профр. С. С. Занковский и Е. В. Абов, вице-президент Союза предприятий печатной индустрии, член Исполкома

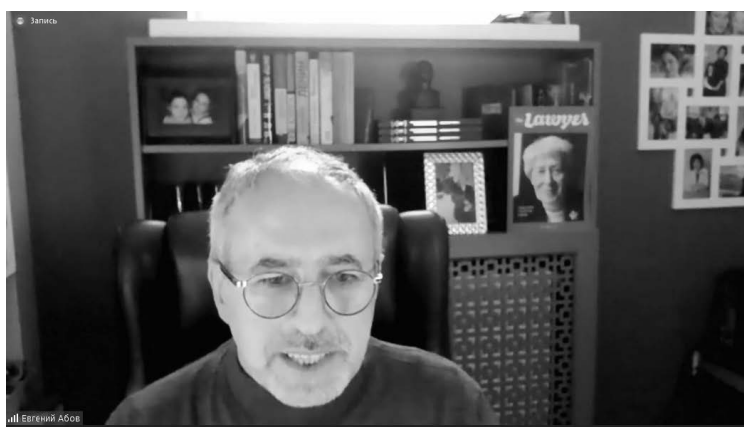
Всемирной информационноиздательской ассоциации, напомнили о том, как в 2019 г. 18 ноября, в день рождения Тамары Евгеньевны Абовой, прошли Первые Абовские чтения, и рассказали об издании сборника материалов конференции. Евгений Владимирович поблагодарил участников конференции за теплые слова о его маме.

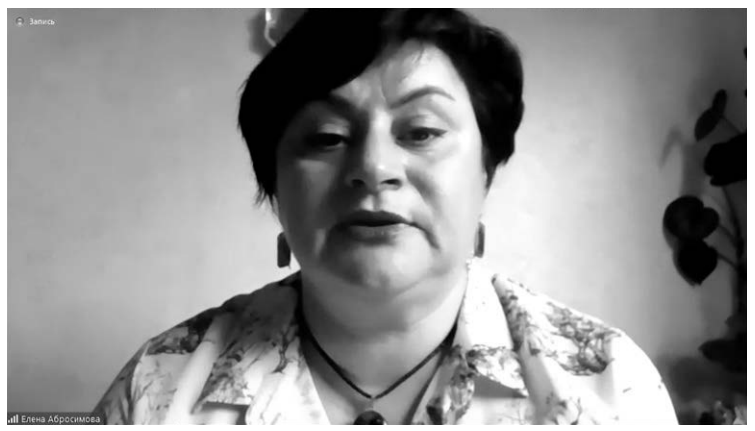

Затем слово было предоставлено Елене Антоновне Абросимовой, зав. кафедрой коммерческого права и основ правоведения Московского государственного университета имени М. В. Ломоносова, д-р юрид. наук, профр. Она выступила с докладом «Развитие российского договорного права под влиянием иностранных моделей». Елена Антоновна рассказала, как на российской почве приживаются такие институты, как корпоративный договор, фракторинг, каршеринг, рамочные договоры, интегрированные маркетинговые коммуникации, договоры, регулирующие программы лояльности, и т. п.

Далее выступила Марина Николаевна Илюшина, зав. кафедрой гражданского и предпринимательского права РПА Минюста России, д-р юрид. наук, профр., с докладом «Решения общих собраний как новое основание возникновения гражданских прав и обязанностей: проблемы становления института». Основное внимание она уделила вопросу о том, как необходимо проводить общие собрания хозяйственных обществ, чтобы избежать рейдерских захватов.

Следующим выступил Сергей Сергеевич Занковский, и. о. зав. сектором гражданского права, гражданского и арбитражного процесса ИГП РАН, д-р юрид. наук, профр. Он рассказал о своем многолетнем сотрудничестве с Тамарой Евгеньевной, о том, каким высокопрофессиональным юристом,

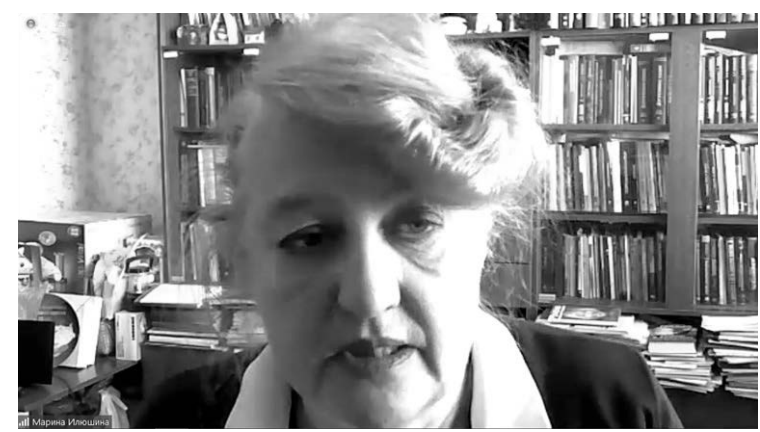




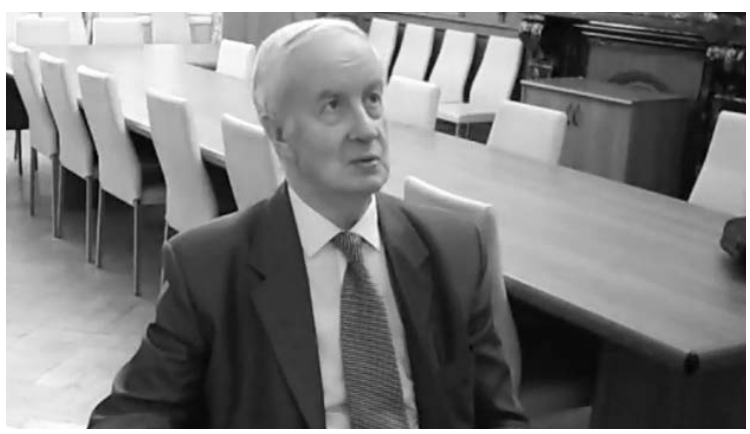

организатором, ученым она была. Помимо этого, Сергей Сергеевич подчеркнул, что Тамара Евгеньевна заслужила любовь коллектива ИГП РАН за сочувствие и готовность помочь, а также за озорной и веселый характер.

Пленарное заседание конференции завершил главный редактор журнала «Третейский суд», старший преподаватель кафедры гражданского процесса СанктПетербургского государственного университета Г. В. Севастьянов, который представил посвященный памяти Тамары Евгеньевны Абовой номер журнала «Третейский суд».

После перерыва работа конференции была продолжена в трех секциях.

Первая секция на тему «Возникновение гражданских прав и их защита: традиционные и новые подходы» (модератор - профр. С. С. Занковский, д-р юрид. наук) началась с доклада «Служебные результаты

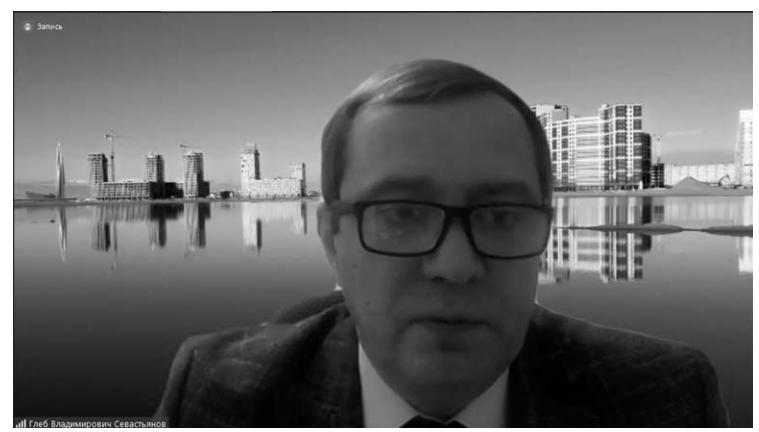
интеллектуальной деятельности: право автора на вознаграждение» профр. кафедры гражданского и предпринимательского права Всероссийской академии внешней торговли Министерства экономического развития Российской Федерации, канд. юрид. наук, доц. Е. Н. Васильевой.

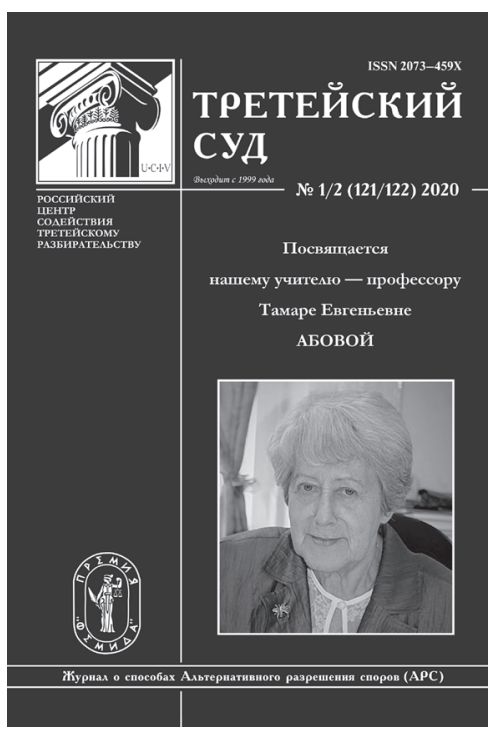

Проблеме договорного регулирования имущественной ответственности в ГК РФ посвятил свое выступление партнер юридической фрирмы «Монастырский, Зюба, Степанов \& Партнеры», канд. юрид. наук Ю. Э. Монастырский. На основе сопоставления положений ст. 15 и п. 4 ст. 401 ГК РФ докладчик отметил ряд существующих противоречий. Критически оценив интерпретацию Верховным Судом РФ нормы о заблаговременном исключении ответственности сторон за грубую небрежность, выступающий пригласил участников секции к дискуссии.

Ст. науч. сотр. сектора предпринимательского и корпоративного права ИГП РАН, канд. юрид. наук, доц. М. Д. Шапсугова подняла проблему взаимодействия неопределенности материального и процессуального статуса самозанятого гражданина. 
Некоторые проблемы создания искусственной задолженности и защиты прав кредиторов при возникновении такой задолженности в своем выступлении затронула доцент кафедры предпринимательского и корпоративного права МГЮА, канд. юрид. наук, доц. Т. П. Шишмарева.

Ст. науч. сотр. сектора предпринимательского и корпоративного права ИГП РАН, кандидат юридических наук С.М. Мотуренко в докладе «Правовые вопросы ликвидации благотворительного фонда» показал возникающие в правоприменительной деятельности трудности при реализации рассматриваемой процедуры и указал на целесообразность законодательного решения вопроса о возможности ликвидации благотворительных организаций во внесудебном порядке, если это инициатива добровольная, не связанная с каким-либо административным преследованием или мерами воздействия.

Особый интерес участников заседания секции вызвал доклад А. А. Пестриковой (Тольяттинский государственный университет; доц., канд. юрид. наук) о правовом режиме биологического материала человека в вещно-правовых отношениях. Докладчик подчеркнула этическую сложность рассматриваемого вопроса, осветила примеры разрешения споров, связанных с вещно-правовым статусом данных объектов, и вопросов, связанных с передачей этих объектов от одного субъекта другому, из зарубежной практики, а также выделила признаки, позволяющие включить рассматриваемые объекты в гражданский оборот.

Сотрудники сектора гражданского права, гражданского и арбитражного процесса ИГП РАН выступили с докладами: о понятии субъективных гражданских прав и способах их защиты - Е. В. Михайлова, ведущ. науч. сотр., д-р юрид. наук, доц.; о страховании как способе защиты интересов сторон при реализации договора строительного подряда - Ю. С. Овчинникова, науч. сотр., канд. юрид. наук; об особенностях правопреемства в вещных и обязательственных правоотношениях - А. В. Пушкина, ст. науч. сотр., канд. юрид. наук; о правовой природе эстоппеля в российской традиции права И. А. Черешнева, мл. науч. сотр.

Отдельные проблемы инвестиционного права нашли отражение в докладах ст. науч. сотр. ИГП РАН, канд. юрид. наук Ю. С. Шпинева и аспиранта Финансового университета при Правительстве РФ С. Н. Жилкибаева.

Закрывая работу секции, С. С. Занковский отметил, что вынесенные на обсуждение вопросы получили разностороннее освещение, поблагодарил коллег за плодотворную работу, интересные доклады и выразил надежду на дальнейшее сотрудничество.

Заседание второй секции было посвящено теме «Возникновение семейных прав и их защита: традиционные и новые подходы». Модератором секции выступила д-р юрид. наук, и. о. зам.директора Института государства и права РАН по научной работе, д-р юрид. наук Н. В. Летова. В своем докладе на тему «Защита семьи, детства, материнства и отцовства в свете новелл Конституции РФ» она отметила заинтересованность государства на современном этапе развития в системной защите института семьи, укреплении семьи, основанной на традиционных семейных ценностях, стабильности семейных отношений и создании условий для полноценного воспитания детей. Докладчик обратила внимание на поправки в Конституцию РФ, касающиеся вопросов семьи, материнства, отцовства и детства, внесенные в 2020 г., которые в соответствии с базовым положением Конституции РФ - принципом 
государственной защиты семьи, материнства и детства в нашей стране - направлены на развитие Конституции Российской Федерации 1993 г., ранее не определявшей понятие семьи и ее состав, не содержавшей развернутых положений о защите именно традиционных семейных ценностей. Н. В. Летова подчеркнула, что семья была и остается одним из главных механизмов воспроизводства и совершенствования общества путем накопления и передачи будущим поколениям опыта, традиций и базовых ценностей.

В работе секции приняли участие ведущие специалисты в сорере семейного права, научные сотрудники и представители юридической практики.

Доклады участников были посвящены самым актуальным темам.

А. Н. Левушкин, д-р юрид. наук, проф., профр. кафедры предпринимательского и корпоративного права Московского государственного юридического университета им. О. Е. Кутафина (МГЮА), обратил внимание на особенности, складывающихся между супругами брачно-семейных отношений, которые порождают множество спорных вопросов при осуществлении ими предпринимательской деятельности, с учетом традиционных и новых подходов. В докладе были проанализированы права и обязанности супругов, защита их прав при участии в бизнес-процессах и осуществлении предпринимательской деятельности, а также проблемные аспекты раздела семейного бизнеса в современный период. Выступающий предложил закрепить на законодательном уровне статус семейного предприятия, чтобы выделить среди субъектов малого и среднего бизнеса особую целевую группу, нуждающуюся в дополнительной государственной поддержке, «семейные предприятия», основанные на семейных связях.

А. А. Серебрякова, доц. кафедры гражданского права и процесса Псковского государственного университета, канд. юрид. наук, доц. в большей степени затронула вопросы семейной правосубъектности. Обратила внимание на защиту прав субъектов правоотношения алиментирования, предложила изменения в действующее семейное законодательство по уточнению категориального аппарата, в целом затронула вопросы права на семейное содержание.

Выступление канд. юрид. наук, доц. кафедры гражданского права и процесса Института права и национальной безопасности Российской академии народного хозяйства и государственной службы при Президенте Российской Федерации (РАНХиГС) М. В. Лебедь было посвящено анализу возможности самозащиты права несовершеннолетних на получение алиментов. Обращено внимание на проблемные аспекты реализации данной возможности, в том числе отсутствие в действующем законодательстве ответственности законных представителей за невыполнение обязанности по взысканию алиментов.

В докладе канд. юрид. наук, доц., ст. науч. сотр. сектора гражданского права, гражданского и арбитражного процесса Института государства и права РАН Л. В. Борисовой, отмечена несогласованность норм действующего федерального законодательства и требований санитарно-эпидемиологических правил, согласно которым проведение термометрии учащихся и других посетителей отнесено к обязанностям всех общеобразовательных организаций. Дана оценка аргументам против реализации данной меры. Высказано предложение по исключению термометрии из перечня процедур, которые могут быть проведены только медицинскими или иными работниками, имеющими право на осуществление медицинской деятельности. 
М. В. Ульянова, канд. юрид. наук, доц. кафедры гражданского права Российского государственного университета правосудия, обозначила необходимость осмысления в науке основных начал семейного права. На основе метода исторического анализа, сравнительно-правового анализа норм международного права, актов международных договоров, имплементированных в законодательство РФ, и иных отраслей российского права докладчик сделала вывод о правовом характере категории «уважение» и отнесении уважения к принципам осуществления семейных прав и исполнения обязанностей; обратила внимание на проблемы субъектного состава в спорах о детях (в частности, по спорам об установлении происхождения детей и спорам о воспитании), где предметом спора являются права и законные интересы ребенка, а также на необходимость приведения в соответствие норм процессуального права и положений материального права.

С сообщением на тему «Способы защиты семейных прав: традиционные и новые подходы» выступила зав. кафедрой гражданского права Пермского государственного национального исследовательского университета, канд. юрид. наук, доц. Т. В. Шершень, которая обратила внимание на отсутствие в семейном законодательстве нормы, содержащей примерный перечень способов защиты семейных прав. В судебной практике возникали вопросы о правовой природе неустойки как способа защиты семейных прав (ст. 115 CK PФ), что в конечном счете привело к дополнению нормы Федеральным законом от 29.07.2018 № 224-ФЗ «О внесении изменений в статьи 114 и 115 Семейного кодекса Российской Федерации» положением о том, что размер неустойки за несвоевременную уплату алиментов может быть уменьшен судом с учетом материального и (или) семейного положения лица, обязанного уплачивать алименты, если подлежащая уплате неустойка явно несоразмерна последствиям нарушения обязательства по уплате алиментов. По мнению докладчика, с доктринальной точки зрения совершенно очевидно, что при защите семейных прав могут быть применены как универсальные, так и отраслевые (гражданско-правовые и семейно-правовые) и межотраслевые способы защиты. В связи с этим необходимо доктринальное осмысление ч. 4 ст. $67^{1}$ Основного закона России о том, что государство, обеспечивая приоритет семейного воспитания, берет на себя обязанности не опекуна или попечителя, а именно родителя в отношении детей, оставшихся без попечения родителей.

Выступление канд. юрид. наук, доц., доц. кафедры конституционного и муниципального права Сибирского института управления Новосибирского государственного университета экономики и управления А. И. Маркеева было посвящено проблеме правового статуса однополых союзов. Обозначены отдельные виды имущественных и личных неимущественных прав, недоступных лицам с нетрадиционной сексуальной ориентацией в России, высказаны отдельные предложения по законодательному закреплению правового статуса таких союзов.

Сообщения участников секции сопровождались вопросами и обсуждением предложенных идей. Мероприятие прошло в теплой дружеской атмосфере.

Третья секция конференции «Актуальные проблемы судебных и внесудебных форм защиты гражданских и семейных прав» была посвящена актуальным вопросам процессуального права. Работа этой секции 
осуществлялась в двух подсекциях, участие в которых приняли известные процессуалисты от Сахалина до Москвы.

В подсекции 1 «Влияние искусственного интеллекта и онлайн-технологий на судебные и внесудебные формы защиты гражданских и семейных прав» (модератор: Лукьянова Ирина Николаевна, ст. науч. сотр. ИГП РАН, канд. юрид. наук) выступления были объединены в несколько тематических блоков.

Были рассмотрены проблемы, возникающие в связи с внедрением искусственного интеллекта (ИИ) в судопроизводство. Проф. С. Ф. Афанасьев, зав. кафедрой арбитражного процесса СГЮА, задал направление дискуссии, указав на две характеристики ИИ в судопроизводстве: 1) ИИ как объект правового регулирования (было высказано предположение о появлении в будущем цифровых процессуальных прав) и 2) ИИ как субъект, отправляющий правосудие. Был поставлен вопрос о том, для чего существует мораль и как она соотносится с ИИ.

Профрессор Е. И. Носырева, зав. кафедрой гражданского права и процесса Воронежского государственного университета, в своем выступлении обозначила второе направление в теме подсекции - проблемы внесудебных форм защиты гражданских прав, сравнив новый институт судебного примирения с медиацией. Было высказано мнение об отсутствии условий для конкуренции между медиацией и судебным примирением как способами АРС. В Воронежской области был один случай использования судебного примирения который оказался безуспешным. Главная причина - отсутствие спроса. Но даже при общем повышении уровня конкуренции между этими процедурами судебного примирения и медиации конкуренция не возникнет. В арбитражном суде сегодня предлагается бесплатная процедура судебного примирения. В этом видится иждивенчество, судебное примирение должно предлагаться ограниченно в арбитражном процессе. В судах общей юрисдикции, напротив, эта процедура должна широко использоваться на бесплатной основе, а медиация - на платной основе в определенных случаях.

Тему электронного правосудия и ИИ продолжила Е. Г. Стрельцова, доц. кафедры гражданского и административного судопроизводства МГЮА, обосновав тезис о том, что такие информационные технологии в судопроизводстве приводят к сокращению непосредственного восприятия судом сведений об обстоятельствах дела, но не влияют на теорию судебного познания. Сахнова Т. В., зав. кафедрой гражданского процесса Сибирского федерального университета, подчеркнула, что внедрение ИИ не должно заменять отправление правосудия человеком, новые технологии должны внедряться в помощь судье и заинтересованным лицам; поставила проблему реализации принципов гражданского процесса в разбирательстве с использованием информационных технологий. Багыллы С. Т., доц. кафедры гражданского и административного судопроизводства РГУП, обратила внимание на необходимость соблюдения баланса между правом на неприкосновенность частной жизни и данными об участниках дела в публикуемых судами сведениях о деле. Интерес участников конференции привлекло выступление И. Н. Спицына, доц. кафедры гражданского процесса УрГЮУ, о юридизации понятия искусственного интеллекта.

Интересное научное сообщение о внедрении в последние годы информационных технологий в деятельность нотариата сделал А. А. Карцхия, профр. кафредры гражданско-правовых дисциплин РГУ нефти и газа им. И. М. Губкина. 
Проблемам арбитражного разбирательства был посвящен специальный тематический блок выступлений. Г. В. Севастьянов, главный редактор журнала «Третейский суд», старший преподаватель кафедры гражданского процесса СПбГУ, канд. юрид. наук, напомнил об опыте пионера нашей страны в использовании видеоконференцсвязи в арбитражных разбирательствах Третейского суда ОАО «ГАЗПРОМ». В своем выступлении он отметил, что ограничения работы арбитража из-за пандемии повлияли на процессуальную форму, и поставил вопрос об адаптации процессуальной формы к условиям пандемии, дополнительных гарантиях процессуального равноправия при разбирательстве на основании документов, использовании видеоконференцсвязи или веб-конференции; а также отметил необходимость трансформации процессуальной формы и разработки ее критериев, чтобы обеспечить процессуальное равноправие сторон и закрепление в регламентах арбитражей правил «процессуального фрорс-мажора».

М. Ю. Савранский, проф. кафедры международного частного права ИЦЧП им. С. С. Алексеева при Президенте РФ, зам. Председателя Арбитражного центра при РСПП (г. Москва), отметил способность Тамары Евгеньевны быть современной, переосмыслить традиционные институты и подходы с позиций современности, а затем остановился на ключевых положениях подготавливаемого Рабочей группой 2 ЮНСИТРАЛ документа об ускоренном арбитраже - проведении разбирательства по документам одним арбитром с представлением ограниченного числа доказательств. Недостатком такого арбитража является, по мнению выступающего, право стороны в любой момент просить о проведении слушаний, и тогда ускоренный арбитраж превратится в «замедленный». В РСПП все слушания сейчас проходят с использованием видеоконференцсвязи и претензий не возникает, что связано в том числе с добросовестностью участников. В таких разбирательствах есть возможность подключать к видеоконференции, например, финансовых специалистов, которым арбитры могут задать вопросы. Отсутствие в регламенте арбитража на возможность использования видеоконференцсвязи оставляет недобросовестной стороне лазейку «торпедирования» решения арбитража заявлением о несогласии с такой формой проведения разбирательства. В 2020 г. были разработаны Руководство Королевского института арбитров по дистанционному разрешению споров, Отчет арбитражной комиссии ICC о применении информационных технологий в арбитраже и Сеульский протокол по использованию видеоконференцсвязи в арбитраже. В последнем следует отметить положения о прекращении сеанса в случае несправедливости в отношении одной из сторон, о допросе свидетеля в нейтральной локации, об идентификации сторон, вопрос о самостоятельной даче показаний свидетелем.

А. Е. Березий, судья Высшего Арбитражного Суда РФ в отставке, зам. Председателя Морской арбитражной комиссии при ТПП РФ, арбитр МАК при ТПП РФ, поднял вопрос о правовой природе обеспечительных мер в морских спорах, связал снижение обращений в МАK с недоброжелательным отношением государственных судов к MKAC и МАK при ТПП РФ. Положение о MAK наделяет Председателя МАK полномочиями принять обеспечительные меры вплоть до ареста судна и груза, находящегося в российском порту. Правовая природа таких мер двойственна. Статья 17 Закона РФ от 07.07.1993 № 5338-I «О международном коммерческом арбитраже» предусматривает 
право Председателя MKA принять обеспечительные меры при следующих условиях: существует исполнимое арбитражное соглашение, иск предъявлен в MAK, обеспечительные меры принимаются до формирования арбитража. Возникает вопрос об исполнимости решения МАK о применении обеспечительных мер, так как п. 51 Постановления Пленума Верховного Суда РФ от 27.06.2017 № 23 «О рассмотрении арбитражными судами дел по экономическим спорам, возникающим из отношений, осложненных иностранным элементом» разъяснялось, что по такому решению Председателя МАK не может быть выдан исполнительный лист. Другой вопрос касается принятия предварительных обеспечительных мер Председателем МАК. Критическая оценка дана мнению о том, что предварительные меры могут применяться только арбитражными государственными судами. А. Е. Березий обратил внимание на предоставляемое Кодексом торгового мореплавания Российской Федерации от 30.04.1999 № 81-Ф3 (KTM) Председателю МАК право принятия обеспечительных мер в виде ареста по морским требованиям, перечисленным в ст. 358 KTM. В самой природе ареста судна по морским требованиям, как это предусмотрено в Конвенции об унификации некоторых правил, касающихся ареста морских судов, 1952 г., заложена возможность принятия предварительных обеспечительных мер до обращения в суд. Иное понимание лишает смысла норму КTM об аресте судов по морским требованиям.

В. В. Хвалей, партнер московского офриса международной юридической фиррмы «Бейкер и Макензи», Председатель Правления Арбитражной Ассоциации, высказал критическое отношение к предложению применять доктрину политических вопросов при решении составом арбитров или впоследствии судом вопроса об арбитрабильности спора в случаях, когда в рамках разрешения исковых требований арбитрам предстоит ответить на вопрос, который может иметь политическое значение.

О.Ф.Засемкова, старший преподаватель МГЮА, остановилась на проблемах онлайн-арбитража и перспективах его развития на примере различных арбитражных институций.

В дискуссии по вопросам, затронутым в блоке об арбитраже, была отмечена значимость лояльности самих сторон к онлайн разбирательству (В. В. Севастьянов).

Блок выступлений, посвященных зарубежному опыту использования информационных технологий в гражданском процессе, вызвал пристальный интерес участников секции. Т.В. Сысуев, доц. кафедры гражданского процесса и трудового права юридического фракультета Белорусского государственного университета, рассказал о внедрении информационных технологий в гражданское судопроизводство Республики Беларусь. Профр. Е. В. Кудрявцева (МГУ) сообщила о текущих результатах проекта цифровизации судов Англии и Уэльса, выявивших в целеполагании проекта проблему баланса доступа к правосудию и экономической эффективности судебной деятельности. Профр. Е. П. Ермакова (РУДН) дала в своем выступлении обзор итогов внедрения информационных технологий в судопроизводство США по трем направлениям: оцифровка судебных актов; онлайн-разбирательства по мелким искам; применение в уголовных делах алгоритмов оценки иска. Ст. науч. сотр. ИГП РАН Н. И. Соловяненко представила основные характеристики юридической модели цифрового пространства доверия для осуществления 
и защиты гражданских прав в российском и зарубежном законодательстве. Ст. науч. сотр. ИГП РАН И. Н. Лукьянова, раскрыла содержание приниипа контроля искусственного интеллекта полъзователем в Европейской этической хартии использования искусственного интеллекта в судопроизводстве. Профр. К. Л. Брановицкий (УрГЮУ) доложил о современном уровне цифровизации правосудия в Германии и иных странах Европы.

Еще один тематический блок был посвящен медиации и иным примирительным процедурам. Ст. науч. сотр. ИЗиСП Н. И. Гайдаенко Шер остановилась на достоинствах и проблемах применения веб-конференцсвязи для проведения процедуры медиации. Е. В. Ситкарева, доц. Всероссийской академии внешней торговли Минэкономразвития России, обратилась к проблемам использования искусственного интеллекта в арбитраже и медиации.

Работу подсекции 2 «Принципы и традиционные институты гражданского и арбитражного процесса: актуальные проблемы» (модератор: Константин Александрович Лебедь, ст. науч. сотр. ИГП РАН, канд. юрид. наук) открыл С. В. Лазарев, судья Арбитражного суда Уральского округа, который обратил внимание на проблему дискреции судьи по вопросу о проведении онлайн-заседаний арбитражного суда: суды могут провести онлайн-заседания, а могут отказать в удовлетворении ходатайства о проведении онлайнзаседаний - в соотношении с гарантиями права быть выслушанным.

М. Е. Поскребнев, доц. кафредры гражданского и административного судопроизводства РГУП, показал в своем выступлении тенденции развития письменных (электронных) и устных процессуальных начал, рассмотрев новые возможности процессуальных норм о веб-конференцсвязи; отметил сложности, возникающие у граждан в связи с доступом к правосудию с использованием новых возможностей. В реплике С. В. Лазарев указал на возникающие при проведении судом онлайн-заседаний технические проблемы.

М. М. Вильданова (ведущ. науч. сотр. ИЗиСП, канд. юрид. наук) затронула проблемы идентификации сторон в гражданском процессе и третейском разбирательстве, в частности вопросы установления судом личности гражданина и полномочий представителя; выделила последовательные действия, связанные с идентификацией и следующей за ней аутентификацией.

М. О. Дьяконова (ст. науч. сотр. ИЗиСП, канд. юрид. наук) в своем докладе осветила особенности электронных судебных извещений с учетом изменений, происходящих в процессуальном законодательстве. В выступлении приведен анализ проблем практического (технического) характера, связанных с доступностью правосудия: должны ли быть электронные извещения обязательными, как определить фракт получения адресатом электронного извещения и др. Обоснован подход, согласно которому извещение в электронном виде должно применяться при наличии согласия лица, участвующего в деле. Введение новых технических средств должно осуществляться таким образом, чтобы у пользователя личного кабинета было достаточно времени для ознакомления с извещением, в то же время в представленных законопроектах это не предусмотрено.

С. И. Князькин, доц. кафредры гражданского и административного судопроизводства РГУП, рассказав о степени влияния информационных технологий на правосудность судебных актов, выдвинул смелые предположения о том, что в среднесрочной перспективе ИИ может заменить людей (судей), 


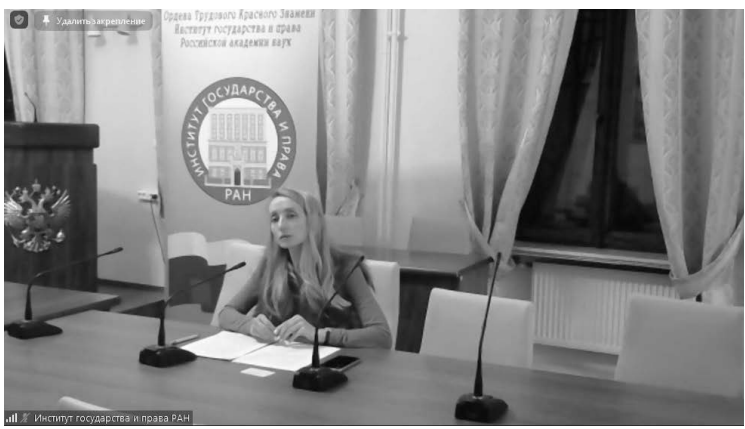

осуществляющих разрешение дел, и вынести при этом справедливое судебное решение. При этом, по мнению докладчика, следует исходить из верховенства права, а не из верховенства закона. В завязавшейся дискуссии приняли участие С. В. Лазарев и М. Е. Поскребнев, высказавшие обоснованные сомнения в скорой и эффрективной замене судей искусственным интеллектом. Участники обсуждения использования новых технологий в судопроизводстве в целом склонялись к тому, что на сегодняшний день рано говорить о реальной возможности широкого использования ИИ для разрешения споров по существу.

А. С. Федина, доц. кафедры судебной власти ТвГУ, канд. юрид. наук, отметила возрастающее значение судебной практики в толковании содержания основных принципов гражданского процессуального права, что привело, например, к усложнению понимания содержания принципа гласности.

Доц. Н. Д. Грибов (РГУП, канд. юрид. наук) в своем выступлении проанализировал права и обязанности сторон в упрощенном производстве (онлайн). Обращено внимание на разницу в реализации прав непосредственно и в режиме онлайн, в частности на право задавать вопросы другим лицам. В упрощенном производстве это право реализовать затруднительно. Особенности приобретают действия, связанные с раскрытием доказательств, представлением отзыва на иск, проявлением уважения к суду и лицам, участвующим в деле.

В работе подсекции приняли участие аспиранты ИГП РАН. О. В. Василенко коснулась важных проблем теории и практики гражданского процесса - раскрыты вопросы реализации основных начал гражданского процесса в условиях увеличения объема использования судами новых (электронных) технологий при рассмотрении и разрешении дел (в том числе - онлайн-заседаний). Н. Т. Надоян остановился на проблемах доказывания по делам особого производства. Е. Н. Толмачева (аспирант РАНХиГС, адвокат) раскрыла психологические аспекты рассмотрения семейных споров. Докладчик отметила, что не всегда в результате судебного заседания конфликт исчерпьвается, хотя судебное решение и выносится по спору. Важно выявить причины конфликта (дисгармонии семейных отношений), динамику развития, определить его этапы.

Завершая работу процессуальной подсекции, К. А. Лебедь отметил важное значение критерия справедливости, разделив при этом законность и справедливость судебного решения.

Поддерживая идеи предыдущего докладчика о справедливости, Т. К. Андреева (зам. Председателя ВАС РФ в отставке, профр. кафедры гражданского процесса МГУ) отметила, что необходимы критерии, позволяющие выстроить целостную конструкцию, чтобы избежать произвольного толкования понятия справедливости. Т. К. Андреева обратила внимание на актуальные вопросы, связанные с внесением поправок в Конституцию РФ (в частности, 


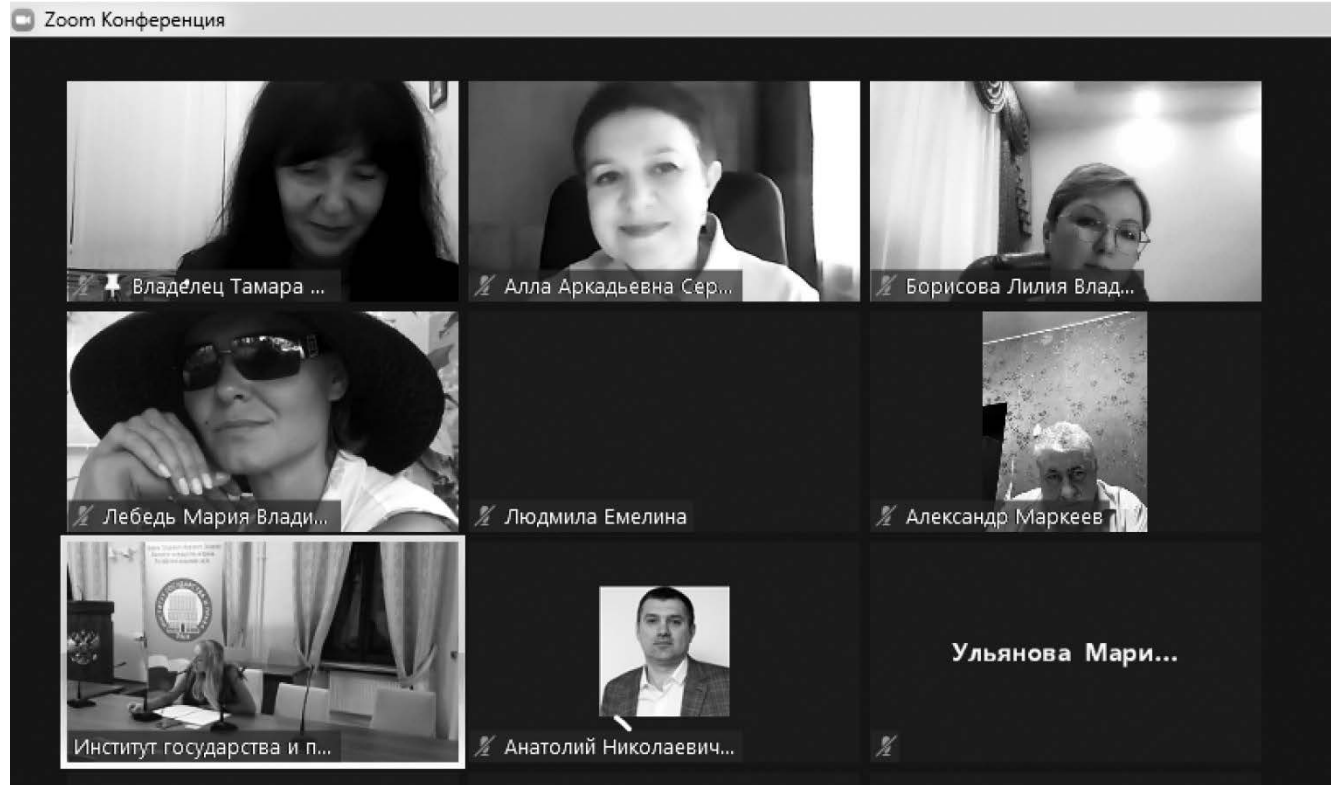

на расширение полномочий Конституционного Суда РФ), а также коснулась проблемы разграничения полномочий судов общей юрисдикции и арбитражных судов.

Представленные на процессуальной секции идеи вызвали живой интерес участников. В дискуссиях по содержанию отдельных выступлений приняли активное участие С. В. Лазарев, М. Е. Поскребнев, М. О. Дьяконова, С. И. Князькин, Н. Д. Грибов, О. В. Василенко, Е. Н. Толмачева, К. А. Лебедь.

Л. В. Борисова, старший научный сотрудник сектора гражданского права, гражданского и арбитражного прочесса ИГП РАН, кандидат юридических наук

K. А. Лебедъ, старший научный сотрудник сектора гражданского права, гражданского и арбитражного прочесса ИГП РАН, кандидат юридических наук

Н. В. Летова, и. о. зам. директора ИГП РАН по научной работе, доктор юридических наук

M. С. Лизикова, старший научнъй сотрудник сектора предпринимательского и корпоративного права ИГП РАН, кандидат юридических наук

И. Н. Лукъянова, стариий научнъй сотрудник сектора гражданского права, гражданского и арбитражного прочесса ИГП РАН, кандидат юридических наук, дочент

А. В. Пушкина, старший научный сотрудник сектора гражданского права, гражданского и арбитражного прочесса ИГП РАН, кандидат юридических наук 